JUnÈs, E. (1925)-Xeroderma pigmentosum avec lésions oculaires. Le X.p. en Tunésie. Arch. d'Ophtal., Vol. XLII, p. 193.

Miescher, G. (1933)-Melanom. Sonderdruck aus Handbuch der Haut-und Geschlechtskrankheiten. Herausgegeben von J. Jadassohn. Springer, Berlin. Vol. XII, Part 3.

Schieck, F. (1931)-Die Erkrankungen der Conjunctiva, Cornea und Sclera, Kurzes Handbuch der Ophthal. Springer, Berlin. Vol. IV.

ZIEBER, KARL. (1938)-Lehrbuch und Atlas der Haut und Geschlech tskrankheiten, p. 203.

\title{
THE PRESENT STATE OF THE PROBLEM OF RETINITIS PIGMENTOSA*†
}

B Y

\section{BIRó}

BUDAPEST

AfTER the clinical characters of retinitis pigmentosa had been defined by the papers of van Trigt, Ruete, von Graefe, Donders and Leber, research turned towards the morphology and histology (Stock, Suganuma, Ginsberg, Koyanagi, Schieck). Later research was directed toward the biological relations of the disease and the field of enquiry was considerably extended by the discovery of endocrinological factors. Investigations of possible connections between retinitis pigmentosa and the pituitary, thyroid, gonads and adrenals did not-all lead to results of lasting value. But even the negative results were important, and the possibilities of endocrine involvement are now limited to the pituitary and the surrounding parts of the diencephalon.

During the latter half of the 30's when the part played by the pituitary and the hypothalamus became obvious, investigations turned to the question of inheritance.

The symptoms and groups of symptoms which so frequently are associated with pigmentary degeneration of the retina and originate. within the pituitary and diencephalon suggest that these areas must play some part in the origin of the disease. The general metabolic disturbances, alterations of the water and salt metabolism, the low body temperature, the hypotony and cholesterinaemia (Lauber, Levy-Wolff) should be ascribed to factors within the diencephalon, and the inhibition of growth, adiposity, polyuria, syndactyly, genital hypoplasia, or polydactyly (Laurence-Moon-Biedl syndrome) are of pituitary origin. Deafness, dumbness, epilepsy, acrocyanosis, Raynaud's gangrene, are

\footnotetext{
* From the Ophthalmological Clinic No. 1, University of Budapest.

+ Received for publication, November 20, 1947.
} 
due to alterations of vasomotor innervation probably through the hormone of the posterior lobe of the pituitary (vasopressin) which plays a decisive part in eliciting them, and is a cause of the everpresent vaso-constriction seen in the fundus.

The appearance of pigmentation is not simply the consequence of an overgrowth of pigment at the site of the atrophy of the neuro-epithelium, but is also due to the effect of the melanophore hormone produced by the intermediate part of the pituitary which regulates pigment distribution.

It is thus evident that typical retinitis pigmentosa is, in the majority of cases, not an independent ophthalmic disease, but a manifestation of a widely branching complex, the nucleus of which is the pathologically altered functions of the pituitary and the diencephalon, and the hormonal consequences thereof. 'The cerebral symptoms associated with the fundus changes (which are in themselves a cerebral manifestation of the disease) correspond with the severity of these pathological disturbances of functions and secretions.

Is every case of retinitis pigmentosa an inherited one? The observations of Nettleship, Redslob, Francéschetti, Bucklers and the author among others, show that the answer is in the negative.

Nettleship as early as 1909 showed that retinitis pigmentosa could follow the acute exanthemata, loss of blood and injury to the blood vessels. Redslob at a meeting of the French Ophthalmological Society ("Ophthalmologica," 1947) showed a girl 14 months old who, a few days after a fever caused by vaccination, lost her eyesight. Her retinal vessels were spastic and her fundus anaemic. After some weeks the vision was gradually restored but the vessels remained narrow and the discs pale. The child was otherwise well, and the Wassermann reaction negative even in her more distant relations. Two years later an examination of the fundus showed typical retinitis pigmentosa.

A similar case was reported by Franceschetti, of a ten year old patient following vaccination. There was no vascular spasm but the discs grew pale, and after some years retinitis pigmentosa developed. Bücklers mentions its occurrence after rubeola and measles., Moreu after malaria, Sudarev after typhus. Redslob in a recent publication states that Lapersonne and Vassaux, as well as Kasas, found the histological signs of retinitis pigmentosa in the fundi of soldiers who had lost their sight from injuries.

The author's own observation concerns a woman of 60 years who in the summer of 1946 complained of a recent rapid loss of sight in the right eye. Vision was "fingers" at 20 inches. The fundus of the affected eye showed a marked degree of vascular 
spasm, both arterial and venous. The disc and fundus were pale. No pigmentary changes were visible. There was no history of any acute illness. General medical and family history were negative, including Wassermann reaction. After an absence of two years she reappeared with the picture of retinitis pigmentosa in the right fundus, the left fundus being still normal. I believe that in this case the disease is to be attributed to some circulatory disturbance of unknown origin.

One-sided cases have been reported by other observers and in only a small fraction of them was it possible to trace a hereditary predisposition, and complications referable to pituitary or hypothalamus were rarely found. It may be concluded that accidental cases of retinitis pigmentosa following the exanthemata, typhus, malaria, wounds, inflammations, persistent vascular spasm and nutrition troubles, are not inherited, not of endogenous origin and not primarily of ectodermal character; and if the fundus picture is the same as that of the hereditary group it can only mean that the causation factors-toxins, etc.-specifically upset the secretory balance of the pituitary and thereby cause a hormonal dysfunction.

I therefore share Redslob's opinion that retinitis pigmentosa should be divided into two classes, the first being the hereditary, and the second the "sui generis" autonomous cases. The inherited affection, as shown clinically by the cerebral complication and histologically by the agreed findings, is primarily a neuro-cellular disease of certain areas of the brain and retinal elements which are structurally and ontogenetically related parts of the ectoderm.

The first group can be further sub-divided into the recessive and dominant types. The great majority are of recessive heredity, while those of dominant inheritance are of slighter degree and are generally free from complications (more than 300 own observations).

The autonomous type are not inherited, and are not systematically connected with the central nervous system.

The sub-division of retinitis pigmentosa into well defined groups ought to have beneficial effects on treatment, which has hitherto been handicapped by want of knowledge of aetiology.

The treatment of inherited forms of retinitis pigmentosa is hopeless, but that of the autonomous group is much more encouraging. The latest form of treatment, that of Filatov, should receive due attention. As far back as 1939 Filatov, in a joint paper with Verbickaja, published favourable results from intramuscular injections of suitably prepared cod liver oil. His 
1945 publication deals with his cornea transplanting methods as well as with his new " tissue therapy." The essentials of this are that suitably prepared and controlled pieces of cornea, conjunctiva, liver, skin, cartilage, placenta, even vegetable matter like aloe leaf, are transplanted into the skin of the patient or beneath the conjunctiva, which substances, according to Filatov, act as " biogenic stimulators," which are not only effective against certain ocular diseases but stimulate also the normal functions of the eye. His method has been tried out on hundreds of patients with such varying disorders as corneal ulcers, trachoma, uveitis and retinitis pigmentosa. Of the last, 110 cases have been treated. No details of the results are available, but from reports reaching us through British and American periodicals (Gordon, Chentsov, Lipkina) interest in the matter is justified. Lacking information regarding the types of cases treated, the percentage of inherited and non-inherited-the forms of investigation with regard to aetiology, etc., it is difficult to express an opinion on the merits of a method, which cannot be denied originality.

The possibility of improvement, even lasting improvement in the autonomous cases cannot be excluded, but we cannot believe in any sort of biogenic stimulation which can alter an inherited pathological state of a part of the brain. This must be kept in mind by everybody who wishes to pursue a scientific attack on the problems of retinitis pigmentosa.

\section{Summary}

Retinitis pigmentosa cannot be regarded as a uniform disease. The author emphasises the dual pathogenesis of the disease as described by Redslob, namely: (1) inherited; (2) " sui generis " or " autonomous."

The inherited group is further divided into those of recessive and those of dominant inheritance.

In contradistinction to the hereditary form the autonomous is a sequel of the acute exanthemata, inflammations, toxic diseases, permanent circulatory impairment, etc., and the hereditary and autonomous-have certain clinical differences.

The latter does not exclude the possibility of permanent improvement, but no treatment can be expected to influence the inherited disease.

\section{REFERENCES}

BIRo.-(a) Brit. Jl. Ophthal., Vol. XXIII, 332, 1939.

(b) Ophthalmologica, Vol. CVII, p. 149, 1944.

BUCKLeRs.-Klin. Monatsbl. f. Augenheilk., Vol. CVIII, p. 380, 1942.

DERIGs.-Inaug.-Diss. Bonn, 1890. Cit. Franceschetti, Leber. 
Donder.s.-Ann.d'Ocul., Vol. XXXIV, p. 270, 1855.

Chentsov:-Vestnik Oftal., Vol. XXV, p. 30, 1946. Ref. Arch. of Ophtal., Vol. XXXVII, p. 684, 1947.

Filatov and Verbickaja.-Vestnik Oftal., Vol. XIV, p. 21, 1939. Ref.Zentralbl., Vol. XLV, p. 104.

Filatov.-(a) Optical transplantation of the cornea and tissue therapy. State publishers of medical literature, Mcscow, 1945. Ref. Excerpta MedicaOphthalmology, Vol. I, p. 5, 1947.

(b) Vestnik Oftal., Vol. XXV, p. 3, 1946. Ref. Arch. of Ophthal., Vol. XXXVII, p. 683.

Franceschetti.-(a) Annales Paediatr., p. 165. No. 4, 1945.

(b) Die Vererbung in Augenleiden. Schieck-Brückner : Kurz. Handbuch d. Ophthal., I. Berlin: 1930.

GinsBerG. - (a) Klin. Monatsbl. f. Augenheilk., Vol. XLVI, II, p. 1, 1908.

(b) Handbuch de spez. Path. Anat. u. Hist., Auge I, p. 432, 1928.

Gordon.-Amer. Jl. Ophthal., Vol. XXX, p. 565, 1947.

GRAEFE.-Graefe's Arch. Ophthal., Vol. IV, II, p. 250, 1858.

KARSCH.-Zentralbl. f. Augenheilk., Vol. XC, p. 157, 1936.

KASAS.-Cit. REDSLOB.

Koyanagi.-Graefe's Arch. Ophthal.. Vol. CXXVII, p. 1, 1931.

LAPERSONNE and VASSAUX.-Arch.d'Ophtal., Vol. IV, p. 86, 1884. Cit. Redslob. LAUBER.-Cit. LEVY-WOLFF.

LEBER.-(a) Graefe's Arch. Ophthal., Vol. XV, I, p. 111, 1869.

- (b) Ibidem., Vol. XVII, I, p. 314, 1871.

(c) Die Krankheiten der Netzhaut. Graefe-Saєmisch. Handbuch Ed. II, Vol. VII, II, p. 1076, 1916.

LEVY-WolfF.-(a) Acta Ophthal., Vol. XVII, p. 192, 1939.

- (b) Amer. Jl. Ophthal., Vol. XXIII, p. 275, 1940. Ref. Zentralbl., Vol. XLVI, p. 393.

Ibidem, Vol. XXIII, p. 418, 1940. Ref. Zentralbl., Vol. XLVI, p. 394.

Lipkina.-Oftal. Jl., Vol. II, p. 29, 1946. Ref. Arch. of Ophthal., Vol. XXXVII, p. $680,1947$.

Moreu.-Arch. Oftal. Hisp.-Amer., Vol. XXXIII, p. 653, 1933. Ref. Zentralbl, Vol. XXX, p. 601 .

NetTLESHiP.-Royal Lond. Ophthal. Hosp. Rep., Vol. XVII, p. 1, 1908.

REDSLOB.-(a) Soc. Franf.-Ophthal.; p. 126, 1935.

(b) Ophthalmologica, Vol. CXIII, p. 290, 1947.

RUETE. - Bildliche Darstellung der Krankheiten des menschlichen Auges. Leipzig, 1854. Cit. FRANCESCHETTI.

SchiEck.-Die Pigmentdegenération der Netzhaut. Kurz. Handbuch d. Ophthal., Vol. V, p. 483. Berlin, 1930.

Schmidt.-Inaug-Diss., Bonn, 1890. Cit. Franceschetti, Leber.

STоск-Klin. Monatsbl. f. Augenheilk., Vol. XLVI, I, p. 225, 1908.

SUdAREv.-Russk. Oftal., pp. 2, 14, 57, 1931. Ref. Zentralbl., Vol. XXVII, p. 171.

Suganuma.-Klin. Monatsbl.f. Augenheilk., Vol. L, I, p. 175, 1912.

van Trigt.-De oospiegel, Nederl., Lancet, Vol. III, p. 492, 1853. Cit. Leber. 